\title{
MANAGEMENT OF MOOREN'S ULCERATION
}

\author{
P. G. WATSON \\ London and Cambridge
}

\begin{abstract}
SUMMARY
Although the diagnosis may be difficult when a patient first presents with Mooren's ulceration, the clinical appearances are characteristic and should not be confused with other conditions which cause corneal ulceration. Based on the clinical presentation and the low-dose anterior segment fluorescein angiographic findings, there seem to be three distinct varieties of Mooren's ulceration: (1) Unilateral Mooren's ulceration (UM), characterised by an excessively painful progressive corneal ulceration in one eye in elderly patients, associated with non-perfusion of the superficial vascular plexus of the anterior segment. (2) Bilateral aggressive Mooren's ulceration (BAM), which occurs in young patients, progresses circumferentially and, only later, centrally in the cornea. Angiography shows vascular leakage and new vessel formation which extends into the base of the ulcer. (3) Bilateral indolent Mooren's ulceration (BIM), which usually occurs in middle-aged patients presenting with progressive peripheral corneal guttering in both eyes, with little inflammatory response. There is no change from the normal vascular architecture on angiography except an extension of new vessels into the ulcer. The management differs in each of these varieties.
\end{abstract}

Mooren's ulcer, which was first described in 1849 by Bowman but became recognised as a specific clinical entity in $1867,{ }^{1-3}$ has always been difficult to treat, partly because of its uncertain aetiology, its variable presentation and unusual geographic distribution.

Mooren described this ulcer as 'a chronic superficial ulcer of unknown aetiology occurring in elderly people, which, with a characteristically undermined border and without perforation, progresses slowly and unrelentingly accompanied by much pain, until the entire cornea may be involved. ${ }^{2,3}$

Characteristically Mooren's ulcers start with an intense limbal inflammation and oedema of the

From: Hon. Consultant Ophthalmologist, Moorfields Eye Hospital, London; Hon. Consultant Ophthalmologist, Addenbrooke's Hospital, Cambridge, UK.

Correspondence to: P. G. Watson, 17 Adams Road, Cambridge CB3 9AD, UK. episclera and conjunctiva but without scleral involvement (Table I). ${ }^{4}$ The corneal changes start to form 2-3 mm from the limbus, appearing first as a grey swollen patch of cornea which rapidly furrows, affecting the superficial one-third of the cornea. The furrow then spreads both circumferentially and centrally but does not perforate the cornea even though the whole surface may be involved. This whole process takes between 4 and 12 months. ${ }^{5,6}$ The bed of the furrow is vascularised, the vessels advancing right into the base of the characteristically undermined edge. The epithelium, although thickened, almost always remains intact throughout the illness.

There has been a tendency among clinicians to call any peripheral corneal destructive change, in the absence of any obvious systemic disease, Mooren's ulcer. This has led to considerable confusion in the literature, making it almost impossible to decide which of the many treatments suggested are likely to be effective in a particular case. With the advent of monoclonal antibody therapy it is now becoming vital that all the immune-mediated diseases are fully characterised in order that the most appropriate therapy can be given.

Since the original description of the disease it has become apparent that there are probably three forms of the disease and that there is a definite racial and geographic variation in the incidences of the disease. $^{5-7}$ The purpose of this paper is to outline the differences between these groups and describe the features which distinguish Mooren's ulceration from other forms of corneal destructive disease, and to discuss the various options for treatment.

Table I. Features of all forms of Mooren's ulceration

Crescent-shaped peripheral corneal ulcer which commences
slightly central to the corneo-scleral limbus
Extensive undermining of the central edge of the ulcer
Stromal yellow/white infiltrates in advance of the ulcer
Central and circumferential progression of the ulcer leaving a
thin vascularised cornea behind
No scleral involvement
No detectable systemic disease




\section{PATIENTS AND METHODS}

This study is derived from a review of 43 patients with Mooren's ulceration for whom records could be obtained, seen by the author between 1963 and 1996 and referred to the scleritis and corneal clinics of Moorfields Eye Hospital, London and Addenbrooke's Hospital, Cambridge. Clinically three patterns of disease were observed: a unilateral aggressive painful disease in old people (UM; 9 patients); a bilateral aggressive disease of young patients, usually of African, Caribbean, Indian or Arabic descent (BAM; 14 patients); and a bilateral indolent form of Mooren's ulceration seen in patients of all origins, the majority being of Indian extraction (BIM; 20 patients) (Table II).

Since 1980 all the patients seen with this disease in the clinics have had low-dose anterior segment angiography ${ }^{8,9}$ in an attempt to define the various forms of this disease more accurately.

\section{UNILATERAL MOOREN'S ULCERATION IN THE ELDERLY (Fig. 1)}

UM is rare, but once seen is never forgotten (Fig. 2). The patient, who is almost always over the age of 60 years, presents with the rapid onset of a red and excessively painful eye, the pain being centred in and around the eye itself. UM is extremely resistant to analgesics, making the patient's life a misery. Only one eye is involved.

On examination of the eye it is found to be red and congested, but the inflammation, which may be intense, does not extent beyond $3 \mathrm{~mm}$ from the limbus. The conjunctiva is suffused but there is no scleral inflammation and no necrosis of the sclera or conjunctiva.
Examination of the cornea reveals the typical features of a Mooren's ulcer, which may progress slowly or extremely rapidly around the globe from a single focal point. Anterior segment fluorescein angiography at this stage reveals venular occlusion of all the local episcleral and conjunctival vessels with the disruption of the limbal arcade and leakage from deep vessels at the limbus and at the base of the ulcer (Fig. 3). The progress of the ulcer is always accompanied by vascularisation of the ulcer bed, and these vessels, which always leak at their tips, run right to the very advancing edge of the ulcer. Left untreated, and sometimes in spite of treatment, the ulcer will advance around the globe and towards the centre. The epithelium of both the base of the ulcer and the remaining cornea remains intact. If the centre of the cornea is observed closely it can be seen to be thicker than normal and, as the disease progresses, becomes more opaque. Eventually the central corneal stroma is removed entirely and all that remains is a thin layer of scar tissue covering an intact endothelium and covered by epithelium derived from conjunctiva. At the time the stromal tissue disappears so does the pain.

Eventually the eye settles down and often the scar tissue retracts sufficiently for the patient to see through the exposed Descemet's membrane. If this happens the patient is best left untreated, unless accidental perforation occurs, because it is almost certain that the same process will recur in the donor cornea of any corneal transplant which is applied. The ulcer in the new cornea starts and progresses in exactly the same way as the original ulcer, even to the extent of not affecting any grafted sclera.

Table II. Differentiating features of the three types of Mooren's ulceration

\begin{tabular}{|c|c|c|c|}
\hline Feature & $\begin{array}{l}\text { Unilateral Mooren's } \\
\text { ulcer (UM) }\end{array}$ & $\begin{array}{l}\text { Bilateral aggressive } \\
\text { Mooren's ulcer (BAM) }\end{array}$ & $\begin{array}{l}\text { Bilateral indolent } \\
\text { Mooren's ulcer (BIM) }\end{array}$ \\
\hline Age & Old & Young & Middle-aged or old \\
\hline Sex & Usually female & Male & Male and female \\
\hline Laterality & Unilateral & Bilateral & Bilateral \\
\hline Clinical course & Extreme pain & Painful & Discomfort \\
\hline Cornea & $\begin{array}{l}\text { All removed rapidly. } \\
\text { Perforation very rare }\end{array}$ & $\begin{array}{l}\text { Deep peripheral ulcers. } \\
\text { Slow central distribution. } \\
\text { May perforate }\end{array}$ & $\begin{array}{l}\text { Slow progression. Usually } \\
\text { peripheral. Perforation rare }\end{array}$ \\
\hline Response to transplantation & Recurrence of disease in graft & Recurrence of disease in graft & Usually accepts transplant \\
\hline Angiography & $\begin{array}{l}\text { Vaso-obliteration of superficial } \\
\text { vascular networks with leakage } \\
\text { from large vessels. Intense deep } \\
\text { leakage. Vascularisation of ulcer, } \\
\text { superficial and deep vessels }\end{array}$ & $\begin{array}{l}\text { Conjunctival and episcleral } \\
\text { networks normal. Intense deep } \\
\text { leakage. Ulcer vascularised from } \\
\text { deep vessels }\end{array}$ & $\begin{array}{l}\text { Superficial networks normal. } \\
\text { Vasodilation of deep network. } \\
\text { Ulcer vascularised from deep } \\
\text { vessels }\end{array}$ \\
\hline Race & Usually white & $\begin{array}{l}\text { Usually African/Indian/Arab/ } \\
\text { Chinese }\end{array}$ & Usually Indian \\
\hline Trigger & Minor trauma/infection & Trauma/infection & $\begin{array}{l}\text { Chronic systemic infection. } \\
\text { Minor ocular trauma or infection. }\end{array}$ \\
\hline Treatment & All treatments unsatisfactory & $\begin{array}{l}\text { Immunosuppression }+ \text { treatment } \\
\text { of any systemic infective disease }\end{array}$ & $\begin{array}{l}\text { Local immunosuppressive } \\
\text { therapy }+ \text { supportive general } \\
\text { treatment }\end{array}$ \\
\hline
\end{tabular}



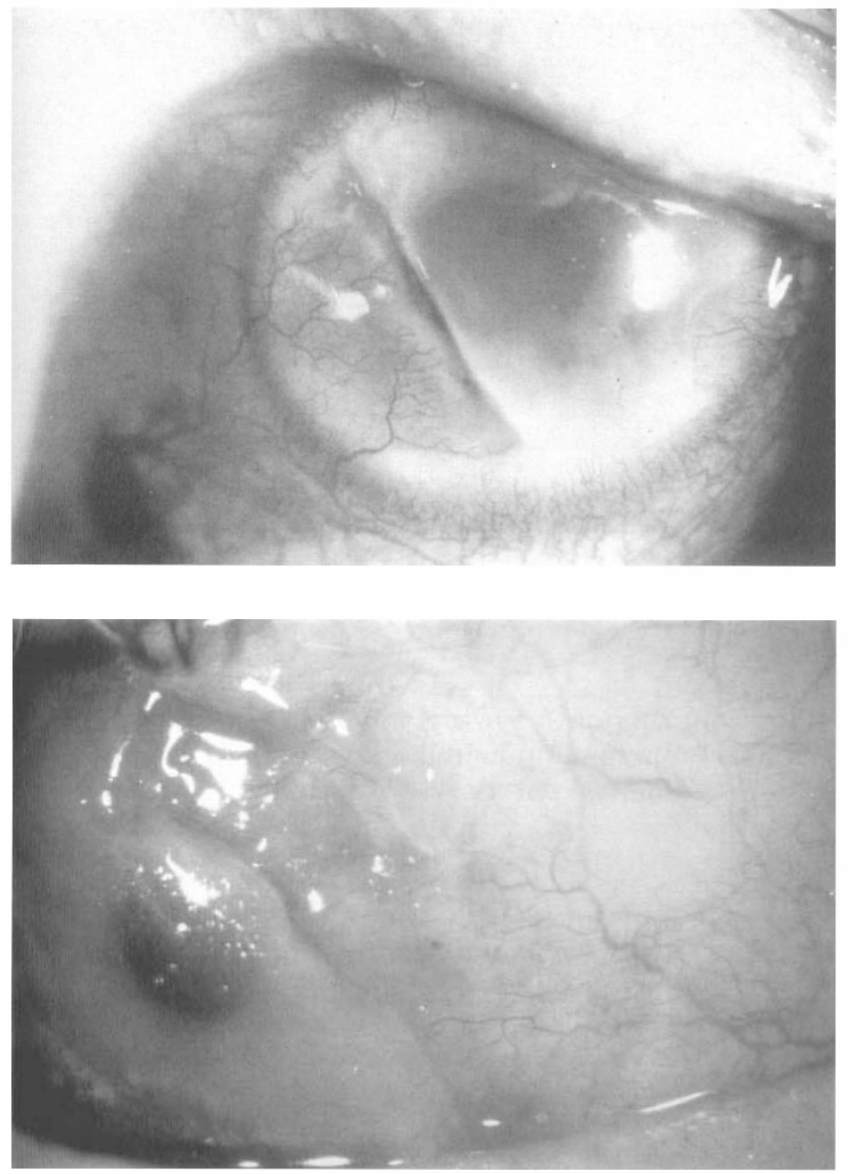

(a)

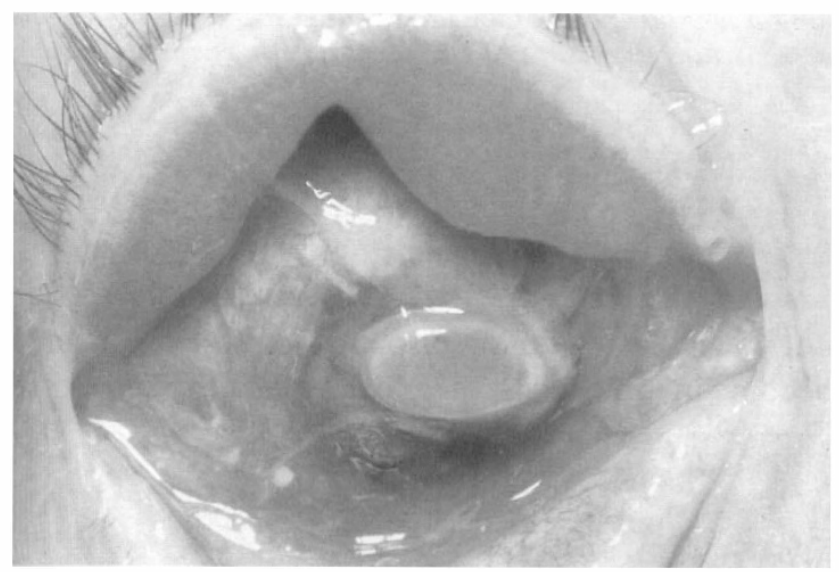

(c)

\section{BILATERAL AGGRESSIVE MOOREN'S ULCERATION IN YOUNG PEOPLE (Fig. 4)}

BAM is most commonly seen in the Indian subcontinent and in communities of Indian origin elsewhere, particularly in East Africa. It is also extremely common in some parts of West Africa. ${ }^{6,10,11}$ The patients, who are usually between the ages of 14 and 40 years, present with painful, but not excessively painful, eyes. When first examined they may have a typical ulcer in one eye but no
Fig. 1. An elderly white patient with unilateral Mooren's ulceration (UM) showing all the typical features of intense limbal inflammation and an ulcer whose advancing edge is undermined and containing many blood vessels. The ulceration is preceded by corneal oedema but the epithelium is intact. (Reproduced from Young and Watson ${ }^{26}$ by permission of the British Journal of Ophthalmology.)

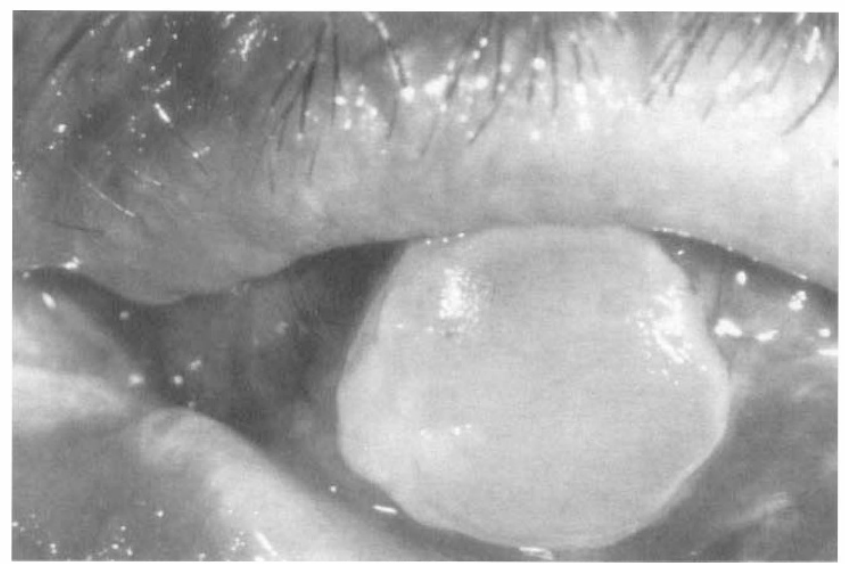

(b)

Fig. 2. (a)-(c) The progression of ulceration in a 65-yearold white woman with unilateral Mooren's ulceration (UM). The photographs were taken approximately 3 months apart. Even though the whole corneal stroma has been removed by the disease, no perforation has occurred and the epithelium has remained intact.

obvious corneal disease in the other, even though the conjunctiva is congested. If this is the case, it is almost certain that, if left untreated, the previously unaffected eye will develop a grey patch within the corneal stroma, followed by others along the limbal margin some $2 \mathrm{~mm}$ from the edge. Within days these grey spots aggregate and tissue is lost, leading to the typical appearance of the Mooren's ulcer (Fig. 4). Angiography reveals changes in the architecture of the episcleral vessels with some areas of closure. 


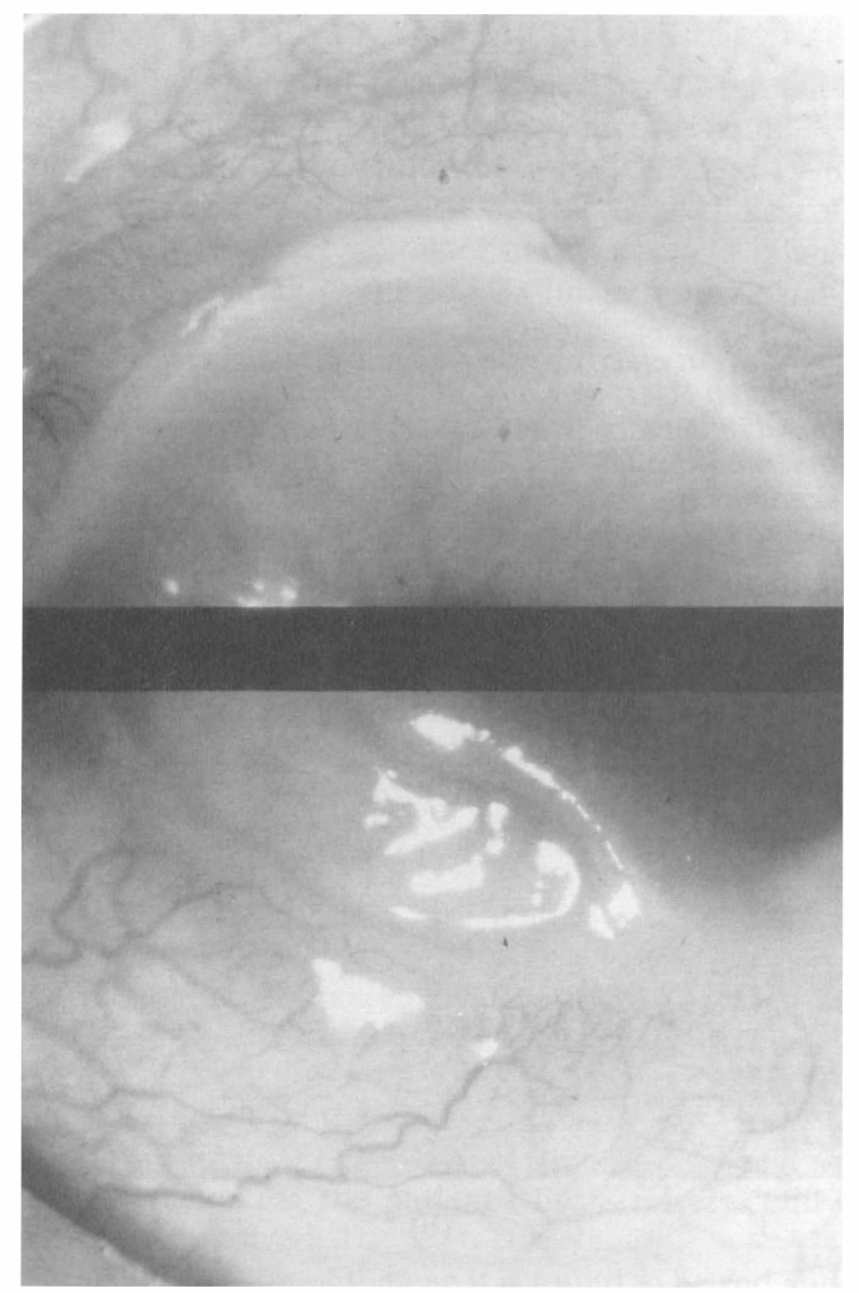

(a)

There are no changes in the conjunctiva, but the angiogram reveals a break-up of the limbal arcade, extension of vessels into the bed of the ulcer and leakage from the tips of these vessels (Fig. 5). The ulcers, unlike the unilateral variety, may perforate spontaneously, and left untreated all the stromal tissue is eventually removed.

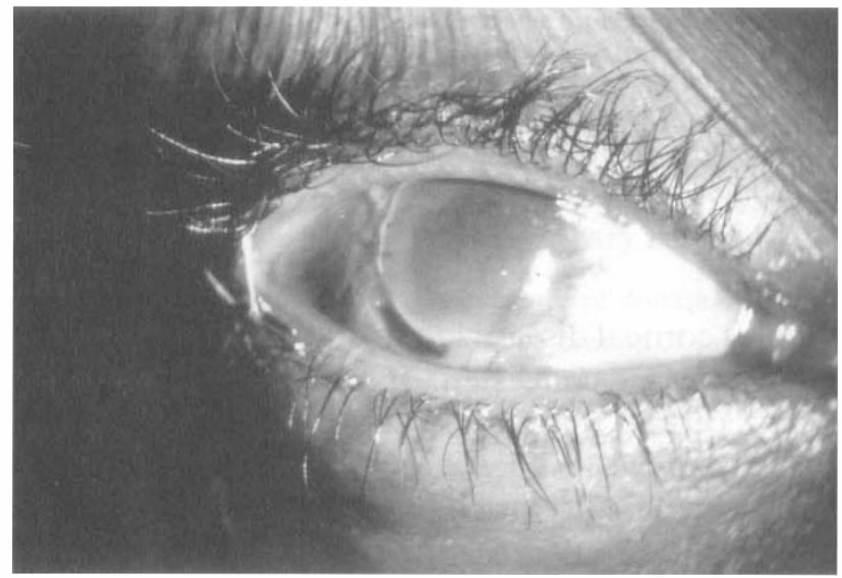

(a)

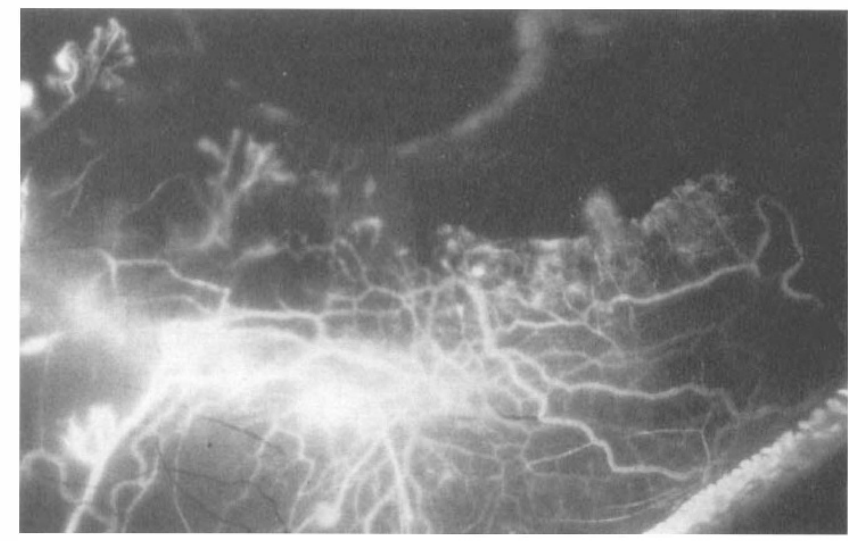

(b)

Fig. 3. (a), (b) Unilateral Mooren's ulceration (UM) in a 75-year-old white man. The angiogram is taken at the advancing edge of the ulcer in the early venous phase. Although there is relatively little obvious inflammation at the limbus the angiogram reveals intensive leakage from the deep vascular plexus in that area. The superficial capillary and venous plexus is non-perfused and there is marked leakage from both the vessels in the ulcer and those in the limbal area, indicating activity of the ulcerative process. The limbal arcade ahead of the advancing ulcer is disrupted and there is non-perfusion of the superficial vasculature in this region.

\section{BILATERAL INDOLENT MOOREN'S ULCERATION IN OLDER PATIENTS (Fig. 6)}

Patients with BIM, who are in their mid-50s or older present with both eyes being uncomfortable, though not particularly swollen or painful. The eyes seem to become involved with the ulceration at the same time

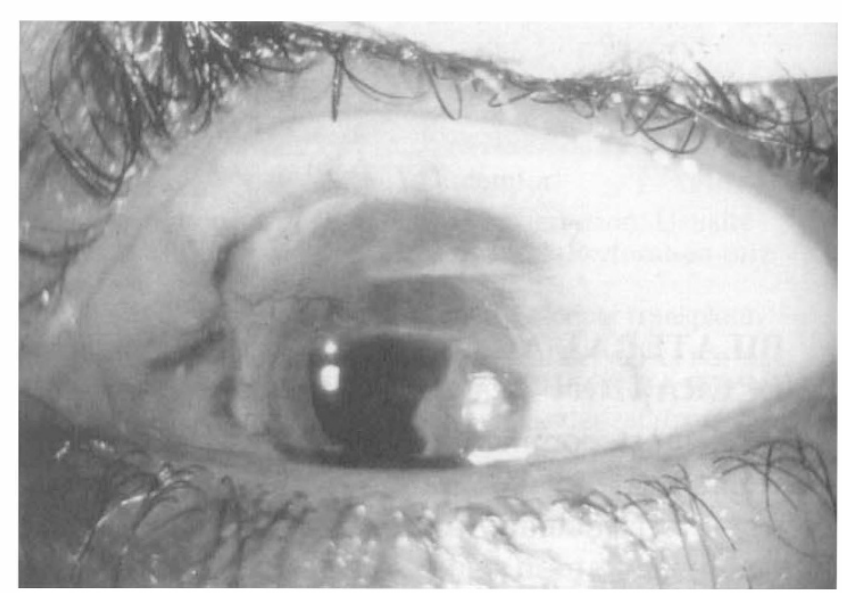

(b)

Fig. 4. (a), (b) Bilateral aggressive Mooren's ulceration (BAM) in a 25-year-old black South African patient. The disea progressed to this stage from its first presentation in under 6 weeks. (Reproduced by permission of Dr S. Sacks, St John Ophthalmic Hospital, Baraguanath, South Africa.) 


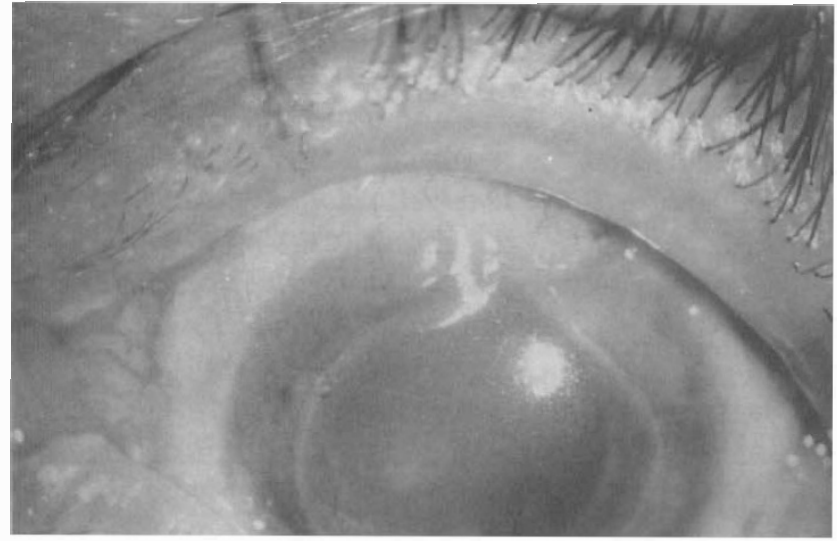

(a)

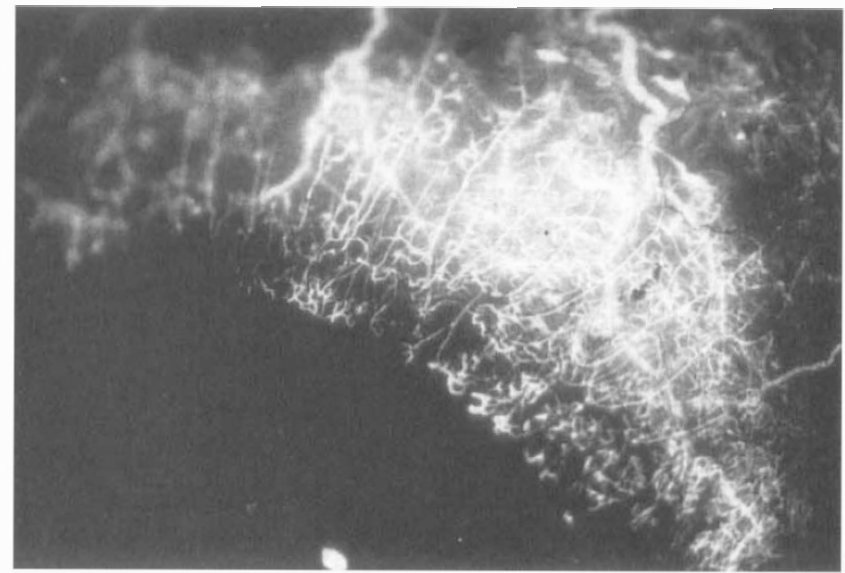

(b)

Fig. 5. (a), (b) Bilateral aggressive Mooren's ulceration (BAM) in a 40-year-old Indian resident in the United Kingdom. Angiography shows marked limbal inflammation with leakage from the deep vascular networks and extension of the vessels into the base of the ulcer. These vessels leak at their tips. However, the superficial vascular plexus, although dilated, is intact and normally perfused.

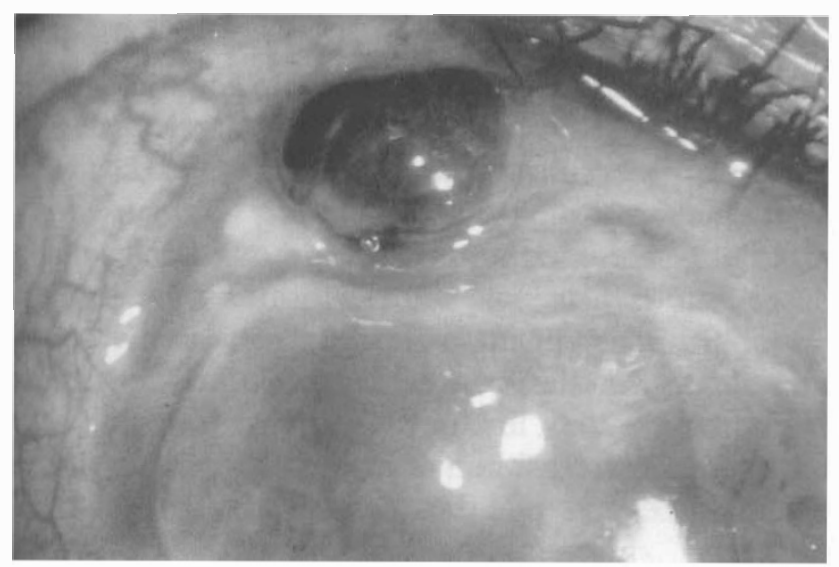

(a)

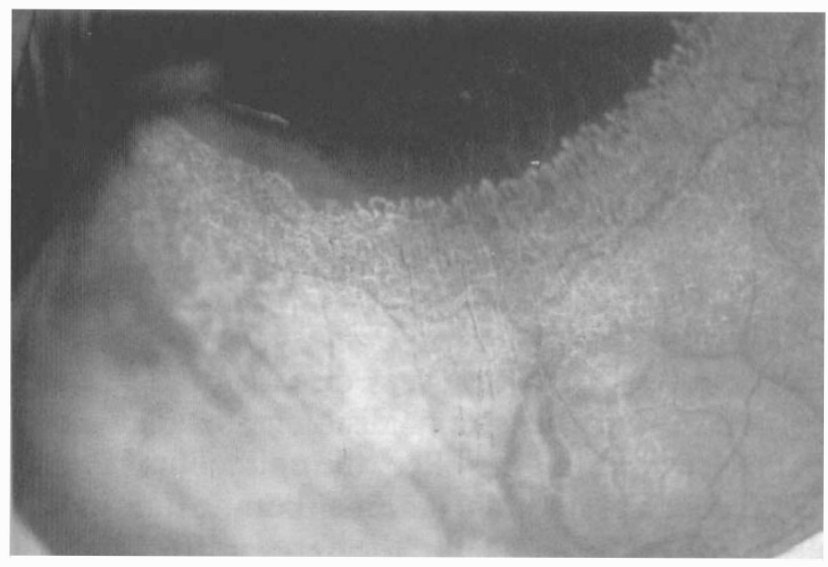

(c)

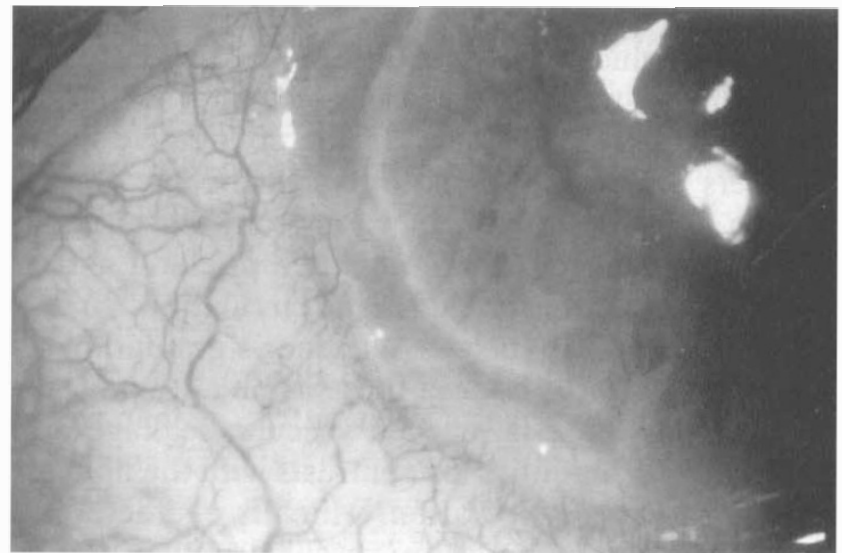

(b)

Fig. 6. (a)-(c) Bilateral indolent Mooren's ulceration (BIM) in a 60-year-old diabetic Arab patient who had a 3 year history of discomfort in both eyes but did not seek advice until minor accidental trauma caused a perforation at 12 o'clock (a). Angiography at the advancing edge of the ulcer shows no changes in the architecture of the superficial vessels and only a very slight vasodilation in the region of the ulcer $(b, c)$. (Reproduced from Color Atlas of Scleritis by permission of Mosby Wolfe.) 
or within days of each other. However, the disease is often much more severe in one eye than the other. The ulcers do not progress aggressively, as in the other two forms of the disease, and, although most are gradually progressive, many will heal spontaneously. Some of these patients may reactivate their disease after a long period, for no obvious reason. Angiography does not show any abnormality in the vasculature of the episceral or conjunctival circulations, only an abnormality of the limbal circulation and changes at the bases of the ulcer (Fig. 6).

\section{DISCUSSION}

It has long been recognised that the presentation of patients with Mooren's ulceration differs in different communities and that at least two types of disease occur. $5,7,10,11$

In this review of 43 patients with Mooren's ulceration, some of whom were investigated with low-dose anterior segment fluorescein angiography, the clinical presentation and racial distribution, together with the angiographic appearances, suggest that there are three different forms of the disorder (Table II).

Angiographically all are different from the other forms of destructive disease associated with the connective tissue disorders. In the connective tissue disorders such as rheumatoid arthritis the angiographic appearances are of vaso-occlusion of capillary and venular circulation of the episcleral and, if severe enough, the conjunctival circulation. In the vasculitic disorders such as Wegener's granulomatosis and periarteritis nodosa these same networks are involved but there is marked vascular leakage and granuloma formation. This contrasts with the appearance in Mooren's ulceration, which is characterised by leakage from the deep vascular networks, i.e. those derived from the long posterior ciliary circulation. In the unilateral form of the disease (UM) there is also poor or absent perfusion of the superficial network; a change also seen to very much lesser extent in some severe cases of the bilateral aggressive disease (BAM). No superficial vascular changes can be detected in the indolent variety (BIM). These changes could be a reflection of the intensity and the difference in ages of the different form of the disease, but investigations so far do not seem to indicate this to be the case, rather that they are specific reactions for the different forms of the disease.

The peripheral corneal ulceration seen in Mooren's ulceration also differs from that found as a result of other degenerative inflammatory or iatrogenic disorders (Table III). The most common form of peripheral corneal ulceration accompanies the severe connective tissue disorders or a systemic vasculitis. Careful clinical observation will enable these various forms to be readily distinguished, and as the
Table III. Causes of non-inectious corneal destruction with inflammation

Irradiation

Beta irradiation

Gamma irradiation

Mitomycin

Conective tissue disease

Rheumatoid arthritis

Systemic lupus erythematosus

Vasculitis

Periarteritis nodosa

Wegener's granulomatosis

Relapsing polychondritis

Mooren's ulceration

treatments for the different types are very specific it is important that this differentiation be made.

Destruction of the peripheral corneal tissue, which can occur with or without scleral changes, is always associated with changes in the limbal and episcleral vasculature. ${ }^{12,13}$ These changes are of dilatation, non-perfusion, leakage and new vessel formation in varying degrees.

The most common form of peripheral corneal ulceration occurs in patients with rheumatoid arthritis in its vasculitic phase. The ulcers start as grey, soft, swollen areas within $2 \mathrm{~mm}$ of the limbus. If there is a scleritis it will usually start in this area but may rapidly extend, the advancing tip of the gutter progressing around the limbus. Rarely, several gutters can occur at the same time and coalesce. The thickness of the cornea may diminish very rapidly if untreated until it is all removed, leaving a descemetocoele which will perforate with the most minor trauma. On angiography the limbal vasculature shows venular non-perfusion and disruption of the limbal arcades, fine new vessels entering the base of the gutter. Epithelial loss is a rarity, and if ulceration occurs it indicates a very severe necrotic reaction.

In patients who have a systemic vasculitis such as Wegener's granulomatosis and periarteritis nodosa the guttering develops in a different way. Characteristically, there is an immediate and intense leakage from the tips of the limbal arcades, which develop small new vessel loops which also leak. ${ }^{14}$ Granulomas develop in both the scleral and corneal side of these changes, destroying the tissue of the limbal area (this does not happen in any other situation). As the disease advances into the cornea the area in front of the advancing edge is grey, infiltrated but not grossly swollen. The new vessels advance to the edge of the guttered area.

Keratolysis is an unusual disease of the central cornea in which the stroma disintegrates. The cornea in the area becomes swollen, the epithelium becomes irregular and may shed. Fine keratic precipitates often develop beneath the area affected. Left untreated the damaged area expands, often with alarming rapidity, to include the surrounding areas, 
until the whole of the stroma is resorbed, leaving only Descemet's membrane which can easily rupture. These changes are often painless and most often seen in patients with long-standing rheumatoid arthritis.

Because of the lack of scleral involvement, or any association with systemic disease, together with the spontaneous regression of inflammation once the stromal tissue has been removed, it has long been supposed that Mooren's ulceration is an immune process, most probably an auto-immune response to corneal stromal tissue. ${ }^{15-17}$ Recent work by Gottsch et al. ${ }^{18}$ has confirmed that the serum of patients with Mooren's ulceration contains antibodies to a corneaassociated antigen ( $\mathrm{Co}-\mathrm{Ag})$ which has been identified to be a tetramer of $7000 \mathrm{Da}$. Antibodies to $\mathrm{Co}-\mathrm{Ag}$ were present in all 15 of the patients who were found to have Mooren's ulceration and none of the controls. No clinical details are given, but if it is found that all three forms of Mooren's ulceration are represented in their series then this indicates that the final pathways to corneal distruction are the same in all cases. However, a protein antigen different from $\mathrm{Co}-\mathrm{Ag}$ and capable of reacting with serum antibodies from patients with Mooren's ulceration (BCP 11/24) has been purified from bovine corneal epithelium by Kruit et al. ${ }^{19}$ Antibodies against corneal epithelium have been found in studies in China,${ }^{20}$ the $\mathrm{UK}^{21}$ and Sierra Leone. ${ }^{22}$ However, they were not present in all the patients and were found in different titres in others. Furthermore, in Sierra Leone the antibodies were present not only in the patients but also in the controls. In the same study controls from subjects in the Netherlands had no antibodies. It is notable that the epithelium remains intact in patients with Mooren's ulceration, so it is possible that this protein is responsible for destruction of the cornea in certain forms of the disease and not in others. It is also possible that this antibody is induced from secondary changes in the epithelium which play a very active role in the transmission of cytokines to the stroma in destructive disease. The distinctive changes which occur have to be mediated through catabolic activity of the fibrocyte in the first instance. This is associated with reduced expression of tissue inhibitor of metalloproteinases (TIMP-1). ${ }^{23}$ Thereafter recruitment of a cellular immune response and cytokine activity perpetuate the destructive process. $^{24-30}$ It was found in studies on destructive diseases of the cornea associated with rheumatoid arthritis that the collagenase activity was much more intense near the epithelial surface and associated with cellular infiltration consisting of activated antigen presenting cells (HLA DR + ), many of which were macrophages (CD 68+) derived from the limbus. ${ }^{23}$ The clinical and histological appearances of Mooren's ulceration would indicate that a similar sequence of destructive change occurs in Mooren's ulceration; however, the angiographic evidence indicates that the main inflammatory response is mediated through the deeper vessels direct to the stroma of the cornea.

The differences in clinical presentation, angiographic appearance and type of tissue destruction of the various forms of Mooren's ulceration compared with those associated with the connective tissue disorders imply a difference in the triggers which induce the auto-immune process in the corneal stroma alone. The unusual geographical distribution might be caused by exposure to different organisms such as hepatitis $C$ virus which could share crossreacting epitopes, or to prolonged exposure to helminthic infection, which, because it causes a heavy antigenic load reduces the ability of the individual to react appropriately against other antigens. ${ }^{21,22,30,31}$ However, in three forms of Mooren's ulceration are found in all races in patients who have lived all their lives in developed countries, indicating that there may well be a genetic difference which allows the disease to develop in a different way.

Whilst the factors which induce Mooren's ulceration are unclear it does appear that there are three clinically and angiographically distinct forms of the disease which respond differently to treatment. In many patients the indolent form of the disease (BIM) resolves spontaneously with improvement in diet and treatment of any systemic infection or re-infestation. Others will respond to very intense (half-hourly) strong steroid preparation locally in addition. Local cyclosporin A may also have a role in these patients. $^{20,32,33}$

BAM is a rapidly advancing, blinding disease and needs aggressive therapy with systemic immunosuppression, initiating treatment with $1 \mathrm{~g}$ methylprednisolone given intravenously followed by local and systemic steroid therapy. ${ }^{4,34}$ It is important to treat any infective process before this if at all possible; if not, simultaneous antibiotic treatment is needed. This treatment may need to be combined with other systemic immunosuppressive therapy, but as other regimes of immunosuppression take about 2-3 weeks to achieve its maximum effect it is not very useful in the acute phase. Corneal surgery should not be attempted if at all possible, and certainly not in the acute phase of the disease until immunosuppression is complete. Cyanoacrylate glue over perforations will sometimes allow healing to occur. ${ }^{35}$ As the maximum inflammatory response is through the deep vascular tissue, excision of limbal tissue would seem to have little if any value in this situation.

Unilateral Mooren's ulceration has been said to be readily treatable. ${ }^{4,7,36}$ This is not the experience in this group of elderly patients, all of whom were unresponsive to treatment. Now that it has been confirmed that the corneal destruction is an autoimmune response to the release of cornea-specific 
antigens, aggressive systemic and local immunotherapy should be used. If this is unsuccessful, then removing the whole of the corneal stroma to the level of Descemet's membrane, which removes the source of the antigen, immediately relieves the intense pain and stops the inflammatory response. ${ }^{37}$ Corneal transplantation is rarely successful in these patients because of a high rate of allograft rejection and a recurrence of the disease process in the graft. Treatment in the future should be possible with specific monoclonal antibody therapy, but until then most patients can see a little through their scar and are usually happy to accept this.

Key words: Mooren's ulceration, Anterior segment fluorescein angiography.

\section{REFERENCES}

1. Robin JB, Scharzlin DJ, Verity SM, et al. Peripheral corneal disorders. Surv Ophthalmol 1986;31:1-36.

2. Mooren A. Ophthalmiatrische Beobachtungen. Berlin: Hirschwald, 1867:107.

3. Mooren A. Ophthalmiatrische Mittheilungen aus den Jahre 1873.

4. Foster CS. Systemic immunosuppressive therapy for progressive bilateral Mooren's ulcer. Ophthalmology 1985;92:1436-9.

5. Nettleship E. Chronic serpiginous ulcer of the cornea (Mooren's ulcer). Trans Ophthalmol Soc UK 1902; 22:103-43.

6. Kuriakose E. Mooren's ulcer. Am J Ophthalmol 1963;55:1064-9.

7. Wood TO, Kaufman HE. Mooren's ulcer. Am J Ophthalmol 1971;71:417.

8. Watson PG, Bovey E. Anteror segment fluorescein angiography in the diagnosis of scleral inflammation. Ophthalmology 1985;92:1-11.

9. Meyer PA, Watson PG. Low dosage fluorescein angiography of the conjunctiva and episclera. $\mathrm{Br} \mathrm{J}$ Ophthalmol 1987;71:2-10.

10. Stilma JS. Conjunctival incision of lamellar scleral autograft in 38 Mooren's ulcers from Sierra Leone. Br J Ophthalmol 1983;67:475-8.

11. Keitzman B. Mooren's ulcer in Nigeria. Am J Ophthalmol 1968;65:679.

12. Watson PG. Vascular changes in peripheral corneal destructive disease. Eye 1990;4:65-73.

13. Watson PG. Pathogenesis of corneal destructive diseases. CIBA Symp Proc 1995;4:60-77.

14. Charles SJ, Meyer PAR, Watson PG. Diagnosis and management of systemic Wegener's granulomatosis presenting with ocular discase. $\mathrm{Br} \mathbf{J}$ Ophthalmol 1991;75:201-7.

15. Linn JG Jr. Chronic serpiginous ulcer of the cornea (Mooren's ulcer): etiologic and therapeutic considerations. Am J Ophthalmol 1949;32:691.

16. Schaap OL, Feltkamp TEW, Breebaart AC. Circulatory antibodies to corneal tissue in a patient suffering from Mooren's ulcer. Clin Exp Immunol 1969; 5:365-70.
17. Mondino BJ. Inflammatory diseases of the peripheral cornea. Ophthalmology 1988;95:463-72.

18. Gottsch JD, Liu SH, Minkovitz JB, Goodman DF, Srinivasan M, Start WJ. Autoimmunity to a corneaassociated stromal antigen in patients with Mooren's ulcer. Invest Ophthalmol Vis Sci 1995;36:1541-7.

19. Kruit PJ, Van der Graaf R, Broersma L, Kijlstra A. Auto-immunity against corneal antigens. I. Isolation of a soluble $54 \mathrm{kD}$ corneal epithelium antigen. Curr Eye Res 1986;5:313-20.

20. Jing-cheng Z, Xiu-ying J. Immunological analysis, and treatment of Mooren's ulcer with cyclosporin A applied topically. Cornea 1993;12:481-8.

21. Murray PI, Pahi AH. Pathogenesis of Mooren's ulcer: some new concepts. Br J Ophthalmol 1984;68:182-7.

22. Van der Gaag R, Abdillah H, Stilma JS, Vetter JCM. Circulating antibodies against corneal epithelium and hookworm in patients with Mooren's ulcer from Sierra Leone. Br J Ophthalmol 1983;67:623-8.

23. Riley GP, Harrall RL, Watson PG, Cawston TE, Hazleman BL. Collagenase (MMP-1) and TIMP-1 in destructive corneal disease associated with rheumatoid arthritis. Eye 1995;9:703-18.

24. Mondino BJ, Brown SI, Robin BS. Cellular immunity in Mooren's ulcer. Am J Ophthalmol 1978;85:788-91.

25. Brown SI, Mondino BJ, Robin BS. Autoimmune phenomena in Mooren's ulcer. Am J Ophthalmol 1976;82:835-40.

26. Young RD, Watson PG. Light and electron microscopy of corneal melting syndrome (Mooren's ulcer). Br J Ophthalmol 1982;66:341-56.

27. Brown SI. What is Mooren's ulcer? Trans Ophthalmol Soc UK 1978;98:390-92.

28. Eifemann RA, Hyndrik RA, Hensley GT. Limbal immunopathology of Mooren's ulcer. Ann Ophthalmol 1978;10:1203-6.

29. Foster CS, Kenyon KR, Greiner J, Greineder DK, Frieland B, Allansmith MR. The immunopathology of Mooren's ulcer. Am J Ophthalmol 1979;88:149-59.

30. Sie Boen Liam, Li Shao Chen. The possibility of a virus aetiology of rodent corneal ulcer (Mooren's). Ophthalmologica 1960;140:311-22.

31. Wilson SE, Lee WM, Murakami C, Weng J, Moninger GA. Mooren-type hepatitis $C$ virus associated corneal ulceration. Ophthalmology 1994;101:736-45.

32. Hill JC, Potter P. Treatment of Mooren's ulcer with cyclosporin A: a report of three cases. Br J Ophthalmol 1987;71:11-5.

33. Wakefield D, Robinson LP. Cyclosporin therapy in Mooren's ulcer. Br J Ophthalmol 1987;71:415-7.

34. Meyer PAR, Watson PG, Frank SW, Dubord R. Pulsed immunosuppressive therapy in the treatment of immunologically induced corneal and scleral disease. Eye 1987;1:487-95.

35. Agrawal V, Kumar A, Sangwan V, Rao G. Cyanoacrylate adhesive with conjunctival resection and superficial keratectomy in Mooren's ulcer. Indian J Ophthalmol 1996;44:23-7.

36. Tabarra KF. Mooren's ulcer. Int Ophthalmol Clin 1986;26:91-8.

37. Gifford S. Delimiting keratotomy. Am J Ophthalmol 1922;5:697. 